DOI https://doi.org/10.30525/978-9934-26-038-4-20

\title{
ПРОГОНОСТИЧНІ КРИТЕРІЇ ВИНИКНЕННЯ ГЕМОРАГІЧНИХ УСКЛАДНЕНЬ ПРИ ГОСТРОМУ ДЕСТРУКТИВНОМУ ПАНКРЕАТИТІ
}

\author{
Колосович І. В. \\ доктор медичних наук, професор, \\ завідувач кафедри хірургії № 2 \\ Національний медичний університет імені О. О. Богомольия
}

\author{
Ганоль І. В. \\ кандидат медичних наук, \\ асистент кафедри хірургії № 2 \\ Національний медичний університет імені О. О. Богомольия
}

\author{
Лебедсва К. О. \\ кандидат медичних наук, \\ асистент кафедри хірургії № 2 \\ Національний медичний університет імені О. О. Богомольия \\ м. Київ, Україна
}

Особливістю перебігу гострого панкреатиту (ГП) є високий ризик розвитку ускладнень, що зустрічаються у 50\% пацієнтів, летальність при яких сягає $5,5 \%$, а при тяжкому перебігу захворювання - варіює в межах 40-70\% [2]. Серед різноманіття ускладнень найбільш небезпечними залишаються тромбогеморагічні ускладнення (ТГУ) та арозивні кровотечі з підшлункової залози (ПЗ), при пізній діагностиці яких летальність може сягати понад 85\% [7]. Слід зазначити, що в тепершній час запропоновано чимало діагностичних шкал (APACHE II, SOFA) та клінічних прогностичних маркерів тяжкого ГП (похилий вік, наявність ожиріння, високий гематокрит та С-реактивний білок) [3], однак всі вони громіздкі та потребують спеціального оснащення.

Мета. Визначення прогностичних критеріїв виникнення та розвитку кровотеч при ГП та покращення результатів лікування хворих шляхом удосконалення методів профілактики арозивних кровотеч з ПЗ в післяопераційному періоді.

Матеріали і методи. У 82 хворих з тяжким перебігом ГП визначали вміст фібриногену в плазмі крові, міжнародне нормалізоване відношення (МНВ), протромбіновий час (ПЧ), активований частковий тромбопластиновий час (АЧТЧ), активність тканинного активатора плазмі- 
ногену (ТАП), активність інгібітора активатора плазміногену типу I (ПАI-1), рівень понаднормованого тромбін-антитромбін III комлексу (ТАТ), а також внутрішньочеревний тиск (ВЧТ). У випадку здійснення оперативного втручання здійснювали контроль активності ферментів підшлункової залози ( $\alpha$-амілаза) у вмісті черевної порожнини. Для порівняння отриманих результатів пацієнти були розподілені на дві групи. В основну групу (30 хворих) увійшли пацієнти, у яких розвинулись арозивні кровотечі, групу порівняння склали 52 пацієта.

Результати та обговорення. У пацієнтів основної групи отримані наступні результати показників згортальної системи крові: фібриноген

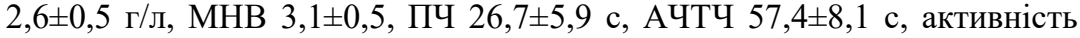

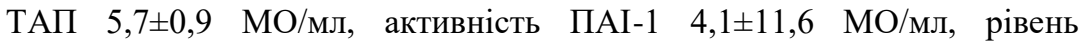
TAT $12,3 \pm 4,3$ нг/мл. Відповідно в групі порівняння - фібриноген $3,8 \pm 0,5$ г/л, МНВ 2,4 $\pm 0,8$, ПЧ $18,2 \pm 4,8$ с, АЧТЧ $42,8 \pm 6,3$ с, активність ТАП 0,8 $\pm 0,6$ МО/мЛ, активність ПАІ-1 38,2 $\pm 12,1$ МО/мл, рівень TAT $1,2 \pm 3,2$ нг/мл. ВЧТ був збільшений в обох групах, однак у хворих основної групи цей показник був вищим $(16,5 \pm 3,6$ мм рт. ст. проти $12,1+1,9$ мм рт. ст.) (Р>0,05). Рівень активності $\alpha$-амілази у вмісті черевної порожнини також був підвищений в обох групах та складав у пацієнтів основної групи $771,7 \pm 188,7 \mathrm{U} / \mathrm{L}$, а групи порівняння $311,2 \pm 288,4 \mathrm{U} / \mathrm{L}(\mathrm{P}>0,05)$. Між показниками активності ТАП, ПАI-1 та рівнем ТАТ виявлено статистично значиму достовірну різницю $(\mathrm{P}<0,05)$.

Наведені дані показників згортальної системи крові зумовлюють необхідність постійного їх моніторингу з метою раннього виявлення передумов винекнення кровотечі у пацієнтів з тяжким перебігом ГП та ï запобіганню. Частота виникнення кровотеч у пацієнтів даної категоpiї, згідно нашого дослідження, може сягати $36,6 \%$, а час виникнення складає $13,8 \pm 10,8$ діб, що відповідає як ранньому, так і пізньому періодам перебігу захворювання. Основним джерелом кровотечі були ерозивно-виразкові ураження шлунково-кишкового тракту $(16(19,5 \%)$ пацієнтів), розвиток яких пояснюється стресових впливом деструктивного процесу в ПЗ та супутньою важкою ендогенною інтоксикацією. У $14(17,1 \%)$ пацієнтів арозивна кровотеча виникла в післяопераційному періоді, що, на нашу думку, було обумовлено, в першу чергу, секретом ПЗ, багатого на протео- та ліполітичні ферменти, під впливом яких може виникнути арозія (руйнування, виразковість, некроз) судинної стінки з розвитком кровотечі.

Аналізуючи процес гемокоагуляції у хворих з тяжким перебігом ГП, можна стверджувати, що захворювання розвивається по типу коагулопатії споживання $з$ активацією та подальшим виснаженням компонентів згортаючої системи, вторинною активацією фібринолізу, i, як наслі- 
док, веде до розвитку синдрому поліорганної недостатності та кровотечі. Серед показників коагулограми найбільшу чутливість у прогнозі розвитку арозивної кровотечі при тяжкому перебігу ГП мали показники активності ПАІ-1 - 90\% і рівень ТАТ - 83,3\%, специфічність цих показників становила відповідно 94,2\% і 92,3\%. Позитивна і негативна прогностична цінність даних показників склала відповідно 90\% і 94,2\% для показника активності ПАІ-1 та 86,2\% і 90,1\% - для ТАТ.

Таким чином, порушення коагуляційного гемостазу та активності ферментів ПЗ вмісту черевної порожнини є провідними етіологічними чинниками виникнення арозивної кровотечі з органу при ГП. Визначення ТАТ та активності ПАІ-1 може використовуватись для скринінгу виникнення кровотечі при тяжкому перебігу ГП.

\section{Висновки:}

1. Тяжкий перебіг гострого панкреатиту характеризується гемокоагуляційними порушеннями та може ускладнюватись розвитком арозивної кровотечі в $36,6 \%$ випадків.

2. Основним джерелом кровотечі при тяжкому перебігу гострого панкреатиту $\epsilon$ ерозивно-виразкові ураження шлунково-кишкового тракту (19,5\% пацієнтів), розвиток яких можна пояснити стресових впливом деструктивного процесу в підшлунковій залозі та супутньою важкою ендогенною інтоксикацією.

3. Визначення рівня ТАТ, активності ПАІ-1 та ТАП дозволяє здійснювати ранню діагностику гемокоагуляційних порушень у хворих 3 тяжким перебігом гострого панкреатиту та прогнозувати можливий розвиток арозивної кровотечі.

\section{Література:}

1. Rasslan R., Novo F., Bitran A., Utiyama E. et all. Management of infected pancreatic necrosis: state of the art. Rev Col Bras Cir. 2017. № 44(5). P. 521-529.

2. Silva-Vaz P., Abrantes A., Morgado-Nunes S., Castelo-Branco M. et all. Evaluation of Prognostic Factors of Severity in Acute Biliary Pancreatitis. Int J Mol Sci. 2020. № 21(12). P. 4300.

3. Nilson E., Santin Andrade R., Aquino de Brito D., Lessa de Oliveira M. [Costs attributable to obesity, hypertension, and diabetes in the Unified Health System, Brazil, 2018Costos atribuibles a la obesidad, la hipertensión y la diabetes en el Sistema Único de Salud de Brasil, 2018]. Rev Panam Salud Publica. 2020. № 44. P. 32. 